\title{
Teletekst, een vergeten medium
}

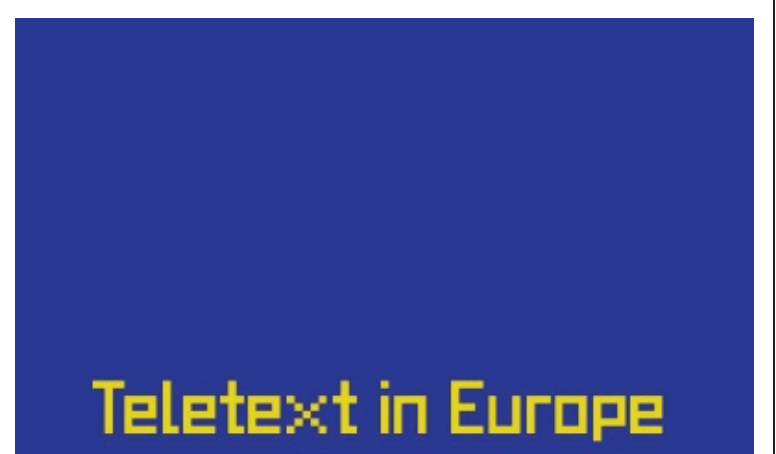

From the Rnalog to the Digital Era

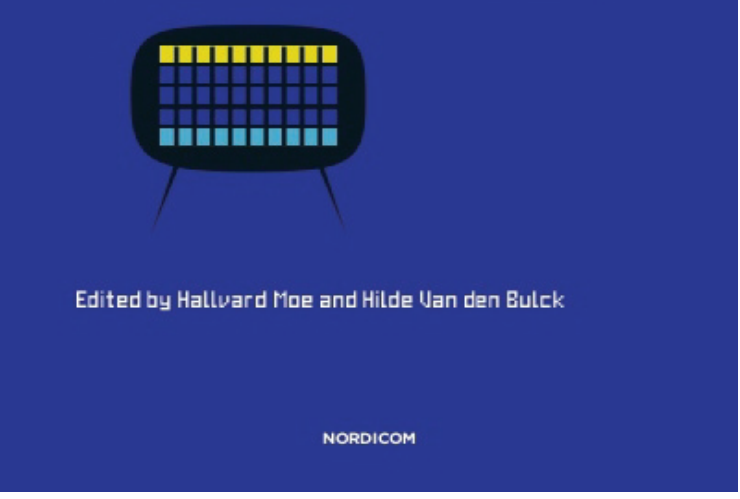

Hallvard Moe and Hilde Van den Bulck, ed.

Teletext in Europe. From the Analog to the Digital Era

Nordicom, 20I6, 259 pp., € 28,- (free pdf download) ISBN 9789I87957208

Er zijn van die media waarover niemand het heeft, maar die er altijd zijn. Ze zijn technologisch niet spectaculair, zelden of nooit omstreden, lijken een eigen uitgesproken stijl te ontberen maar worden deerlijk gemist als ze verdwijnen. Teletekst is zo'n medium. Begonnen als een zijproduct van televisie, letterlijk in de technische rafelranden van het televisiesignaal weggestopt, is de dienst in meer dan veertig jaar uitgegroeid tot een snelle leverancier van nieuws en informatie op het televisiescherm. Saai, degelijk, maar altijd actueel en vooral ook kort en bondig, dat was teletekst. De actualiteit en bondigheid heeft het met Twitter gemeen, maar Twitter is een miljoenenbusiness waarover iedereen spreekt. Teletekst wordt in sommige landen geruisloos afgeschaft (zoals momenteel in Vlaanderen) of geleidelijk afgebouwd. Helaas is het medium ook nog eens nauwelijks gearchiveerd, zodat het misschien daadwerkelijk gaat lijken alsof het nooit bestaan heeft.

Waarom heeft zo'n medium ogenschijnlijk geen geschiedenis? En waarom trekt teletekst nauwelijks wetenschappelijke belangstelling? Dat zijn de uitgangspunten geweest van een wetenschappelijke ECREA-conferentie in Lissabon in 20I4. Onder redactie van de Noorse hoogleraar Mediastudies Hallvard Moe en de Antwerpse hoogleraar Communicatiewetenschap Hilde Van den Bulck zijn de bijdragen van die conferentie nu gebundeld. Daaruit blijkt dat teletekst bepaald nog niet overleden is. In tegenspraak tot de vele ondergangsprofetieën die na de groei van internet waren te horen, kent teletekst nog miljoenen gebruikers in landen zoals Finland, IJsland, Noorwegen en Nederland.

Dat heeft wellicht iets te maken met de gebreken van het technologisch deterministisch denken, dat veel discussies rond nieuwe mediatechnologie doordrenkt. Het onuitroeibare uitgangspunt in dat denken is dat de technologie de ontwikkelingsgang van mediainnovatie domineert. In dat licht vallen sociale en culturele factoren meestal weg of worden als niet volwaardig gezien. Juist die componenten kunnen echter bepalend zijn voor het succes (of het ontbreken daarvan) van innovaties. 
Technologisch deterministen hebben daarom vaak moeite met het verklaren van de doorbraak van technische vindingen die niemand had voorzien.

Een uitstekend voorbeeld is dan teletekst. Niemand had voorzien welk gebruik die innovatie zou krijgen toen de BBC in 1972 Teletext introduceerde als een service voor doven en slechthorenden. Met de in teletekst opgenomen ondertiteling kon deze groep toch televisie genieten. Maar spoedig bleken onverwachte andere toepassingen van wat spoedig als Ceefax bekend zou staan. Want in het teletekstdatabestand konden naast ondertitels ook nieuwsberichten en extra informatie worden opgenomen. De kortheid en feitelijkheid daarvan (Ceefax is een verbastering van 'see the facts') bleken aantrekkelijk voor een breed publiek dat op zelfgekozen tijdstippen nuttige informatie kon oproepen.

In jaren tachtig kreeg Ceefax dan ook veel navolging. Daarvan zijn in deze bundel vele voorbeelden te vinden. De meest intrigerende daarvan is wellicht de studie van Lyombe Eko naar de ontwikkeling in Frankrijk. Daar was in I972 teletekst begonnen als 'Antiope', waarachter een krachtig beleid schuilde om de Franse cultuur te verdedigen tegen de dreigende overvloed aan Angelsaksische televisie. Antiope werd begin jaren tachtig zelfs het uitgangspunt voor een van de meest ambitieuze pogingen ooit om alle burgers in een nationale samenleving te voorzien van alle denkbare informatie, een typisch Frans 'Grand Project' dat strakke en bureaucratische centrale sturing met inzet van miljoenen francs vergde.

Het project Télétel/Minitel dat daaruit voortvloeide, kende een strategie die twintig jaar later via geheel andere weg in internet zou uitmonden. De teletekst-technologie zou worden samengevoegd met de nieuwste mogelijkheden om ook beeld erin te vervlechten, de zogenaamde videotext-technologie. Daarbij was voorzien in een interactieve dienst; gebruikers konden via de telefoonlijn inbellen op alle denkbare datadiensten en daar grasduinen naar wat van hun gading was. Met het Franse succes (begin jaren negentig waren miljoenen Franse huishoudens via het miniteltoetsenbordje aangesloten op vele datadiensten) leek de verwezenlijking van een democratisch ideaal naderbij. Maar ook de verwezenlijking van onverwachte - en voor sommigen onwenselijke of immorele - verlangens: de populairste bronnen in het minitelsysteem bleken pornografische bulletin boards te zijn, de zogenaamde Minitel Roses.

De beruchte gammele minitel-terminals die via de telefoonlijn en de kabel toegang tot informatiediensten bood, leken hun tijd ver vooruit. Maar wie de wet van de remmende voorsprong kent, weet dat vooruitgeschoven innovaties op lange termijn ook kunnen veranderen in een desastreus nadeel. De opkomst van internet ging ook niet aan de Franse samenleving voorbij, waardoor via deze weg de veel gevreesde vloed aan Angelsaksische cultuur toch plaats vond. De upgrading van het systeem met i-Minitel in 2005 kon niet verhinderen dat het aantal betalende gebruikers daalde naar twee miljoen in 2009. Vele pogingen het zieltogende systeem toch nog te redden waren tevergeefs; in 2012 werd de stekker er definitief uitgetrokken, volgens Eko 'because of its bureacratic over-centralization, its narrow, national cultural focus, and the failure of its operators to think globally.'

Dat is overtuigend, maar het neemt toch niet weg dat sociaal gebruik van nieuwe mediatechnologie zich zelden goed laat voorspellen. Zo is de vraag onopgelost waarom teletekst in sommige landen nog steeds heel veel gebruikt wordt, terwijl in buurlanden er gering publiek animo voor bestaat. Ook in deze bundel is er 
geen bevredigend antwoord te vinden. Wel maken de redacteuren overtuigend duidelijk dat teletekst een mooi voorbeeld is van remediation; het in academische kring veel besproken historische proces van interactie tussen oude en nieuwe media. Daarbij vormt de inhoud van 'oude' media aanvankelijk de basis voor de nieuwe, waarna in een geheel eigen dynamiek de oude media zich herdefiniëren en de nieuwe voorop gaan lopen met de ontwikkeling van vormen die aan hun eigen logica zijn gebonden. Teletekst was het nieuwe medium van de jaren tachtig, maar is nu geworden tot een wat vergeten maar nog steeds levend 'oud' medium. Waarschijnlijk omdat het zich in tal van landen heeft geherdefinieerd zowel ten opzichte van de voorkant van digitale televisie als ten opzichte van de internettechnologie.

In dit opzicht geeft deze bundel beschouwingen stof tot nadenken over de waarde van de remediation-theorie. En ook over het technologisch determinisme dat merkwaardigerwijs nog steeds dominant is in alle reflectie over doel en richting van technologische innovatie.

Huub Wijfes, Rijksuniversiteit Groningen / Universiteit van Amsterdam 